\title{
DNA lability induced by nimustine and ramustine in rat glioma cells
}

\author{
KATSUYOSHI MINEURA, SUSUMU FUSHIMI, YASUNOBU ITOH, \\ MASAYOSHI KOWADA
}

From the Neurosurgical Service, Akita University Hospital, Akita, Japan

SUMMARY The DNA labile sites induced by two nitrosoureas, nimustine (ACNU) and ramustine (MCNU) synthesised in Japan, have been examined in highly reiterated DNA sequences of rat glioma cells. Reiterated fragments of 167 and 203 base pairs (bp), obtained after Hind III and Hae III restriction endonuclease digestion of rat glioma cells DNA, were used as target DNA sequences to determine the labile sites. In vitro reaction with ACNU and MCNU resulted in scission products corresponding to the locations of guanine. Subsequent piperidine hydrolysis produced more frequent breaks of the phosphodiester bonds at guanine positions, thus forming alkali-labile sites.

Nitrosourea compounds have been used frequently as effective chemotherapeutic agents against malignant gliomas.' The synthesised antitumour drugs 1-(4amino-2-methyl-5-pyrimidinyl)methyl-3-(2-chloroethyl)-3-nitrosourea hydrochloride (nimustine, ACNU) and methyl-6-[3-(2-chloroethyl)-3-nitrosoureido]-6-deoxy- $\alpha$-D-glucopyranoside (ramustine, MCNU) have also been reported as enhancing therapeutic effectiveness in the chemotherapy of malignant brain tumours. ${ }^{23}$ However, the mechanisms involved in their tumour cell-killing effects and DNA interactions are still unclear.

This paper presents a DNA sequencing analysis of in vitro interactions of $A C N U$ or MCNU with cellular DNA, and characterises the DNA sites labile to these nitrosoureas.

\section{Materials and methods}

C6 and 9L cell lines were established from gliomas in rats, ${ }^{45}$ and were maintained in Eagle's MEM Earle medium supplemented with $10 \%$ fetal bovine serum at $37^{\circ} \mathrm{C}$ in a humidified atmosphere of $5 \% \mathrm{CO}_{2}$ in air. Cells at the exponential growing stage were trypsinised, and were lysed in $1 \%$ sodium dodecyl sulphate in $0.15 \mathrm{M}$ sodium chloride, $0.015 \mathrm{M}$ sodium citrate ( $\mathrm{pH} \mathrm{7.4)}$ buffer. The lysate was digested by RNase $(100 \mu \mathrm{g} / \mathrm{ml})$ for $60 \mathrm{~min}$ and then Pronase $(500 \mu \mathrm{g} / \mathrm{ml})$ for at least 3 hours at $37^{\circ} \mathrm{C}$. After protein removal using chloroform-isoamyl alcohol (19:1 vol/vol) and

Address for reprint requests: Katsuyoshi Mineura, MD, Neurosurgical Service, Akita University Hospital, 1-1-1 Hondo, Akita 010, Japan.

Received 15 September 1987 and in revised form 31 May 1988. Accepted 24 June 1988 distilled phenol, the extracted DNA was dialysed extensively against Tris-EDTA buffer (10 mM Tris- $\mathrm{HCl}, 1 \mathrm{mM}$ EDTA pH 8.0).

The DNA was digested with Hind III restriction endonuclease (Boehringer, 1 unit/ $\mu$ g DNA) for 3 hours in medium salt buffer (20 mM Tris- $\mathrm{HCl}$ pH 7.6, $50 \mathrm{mM} \mathrm{NaCl}, 6 \mathrm{mM}$ $\mathrm{MgCl}_{2}, 0 \cdot 1 \mathrm{mg} / \mathrm{ml}$ gelatin, $6 \mathrm{mM}$ 2-mercaptoethanol). The reacted DNA was located on a $4 \%$ polyacrylamide gel and stained with $10 \mu \mathrm{g} / \mathrm{ml}$ ethidium bromide for 15 minutes. A 370 base pair (bp) fragment was recovered from the gel by electrophoresis. ${ }^{6}$ The $370 \mathrm{bp}$ fragment was labelled at the $3^{\prime}$ end with $\left[\alpha{ }^{32}\right.$ P]dATP (New England Nuclear Products, $3000 \mathrm{Ci} / \mathrm{mmol}$ ) for $30 \mathrm{~min}$ at $15^{\circ} \mathrm{C}$ by the Klenow fragment of $E$ coli DNA polymerase I (Boehringer). The reaction mixture contained $20 \mathrm{mM}$ Tris- $\mathrm{HCl}(\mathrm{pH} \mathrm{7.6)}, 6 \mathrm{mM} \mathrm{MgCl}, 6 \mathrm{mM}$ $\mathrm{NaCl}, 6 \mathrm{mM} 2$-mercaptoethanol, $0.1 \mathrm{mg} / \mathrm{ml}$ gelatin, $100 \mu \mathrm{Ci}$ of $\left[\alpha{ }^{32}\right.$ P]dATP, $100 \mu \mathrm{M}$ dGTP, $100 \mu \mathrm{M}$ TTP, $100 \mu \mathrm{M}$ dCTT, $1-5 \mu \mathrm{g}$ DNA, and 1 unit of enzyme in $50 \mu \mathrm{l}$. After ethanol precipitation, labelled DNA was once again digested with Hae III in medium salt buffer at $37^{\circ} \mathrm{C}$ for 2 hours. 167 and $203 \mathrm{bp}$ fragments were isolated on a $4 \%$ polyacrylamide gel. DNA sequencing reactions were performed according to Maxam and Gilbert.'

The 3'-end labelled 167 or 203 bp fragment was reacted with ACNU or MCNU in Tris-EDTA buffer at $37^{\circ} \mathrm{C}$ for varying incubation times, up to 2 hours. The drug concentrations ranged up to $1 \mathrm{mM}$. After ACNU or MCNU reaction, half of the sample was lyophilised and directly dissolved in loading buffer ( $80 \% \mathrm{vol} / \mathrm{vol})$ deionised formamide, $50 \mathrm{mM}$ Tris-borate pH 8.3, 1 mM EDTA, 0.1\% (wt/vol) zylene cyanol, and $0 \cdot 1 \%(\mathrm{wt} / \mathrm{vol})$ bromophenol blue). The other half of the sample was lyophilised, redissolved in $1 \mathrm{M}$ piperidine and incubated at $90^{\circ} \mathrm{C}$ for $30 \mathrm{~min}$, and then repeatedly lyophilised and dissolved in loading buffer. Samples were heated at $90^{\circ} \mathrm{C}$ for $1 \mathrm{~min}$ in loading buffer before electrophoresis on sequencing gels ( $8 \%$ polyacrylamide, $50 \%$ urea). Gels were subjected to autoradiography overnight with a Kodak Quanta III intensifying screen. 


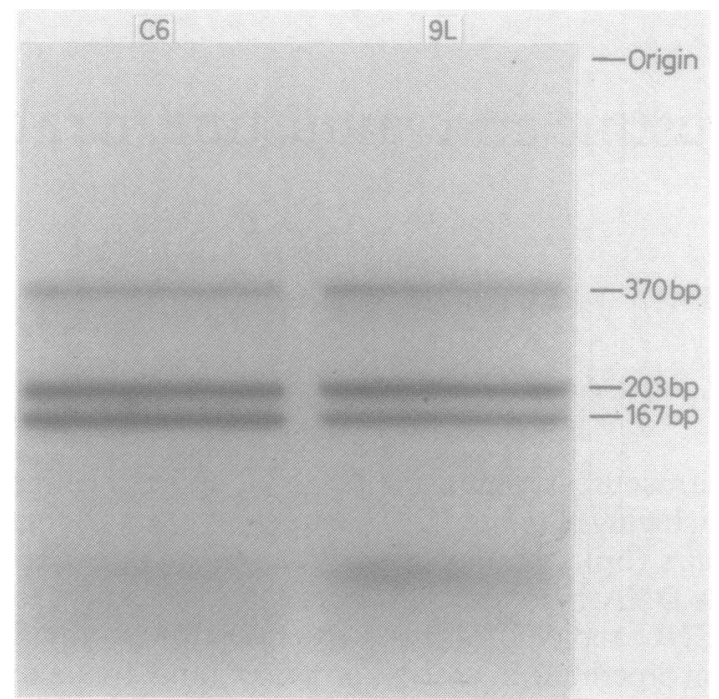

Fig 1 Autoradiogram after 3 '-end labelling and recutting at Hae III site GGCC (G:guanine, C:cytosine) of the 370 bp fragment purified from rat glioma C6 (left) and $9 L$ (right) cells.

\section{Results}

The amount of the $370 \mathrm{bp}$ fragment obtained from at least $10^{7}$ cells was sufficient and suitable for one sequencing experiment. The 3 '-end labelled $370 \mathrm{bp}$ fragment was clearly cut into 167 and 203 bp fragments after Hae III digestion, as shown on a $4 \%$ preparative gel (fig 1). Sequence homologies between $\mathrm{C} 6$ and 9L cells were recognised in the 167 and $203 \mathrm{bp}$ fragments; these were identical to the consensus sequence for the 370 bp satellite DNA I obtained from Hind III-digested rat DNA. ${ }^{8}$

Reaction of the end-labelled DNA fragments with ACNU or MCNU generated prominent bands, corresponding to positions of guanine in the original sequence through chemical cleavage (fig 2). The amount of radioactivity in bands corresponding to breakage at guanine positions was considerably higher than that observed for any other base. Subsequent piperidine reaction more frequently broke the phosphodiester bonds at guanine positions.

As the ACNU or MCNU concentration increased, the intensity of the guanine bands also increased, indicating that under the standard conditions used, cleavage at guanine is semiquantitative. In addition, an increase in band intensity after ACNU or MCNU treatment was seen with prolongation of the reaction time. At the same molar concentration, the amount/ extent of DNA breaks were not significantly different between ACNU and MCNU. Furthermore, the degree of scission products were similar in two rat tumour cell lines under the same reaction conditions. These scission products generated by ACNU or MCNU, with or without piperidine hydrolysis, were identical under reaction conditions ranging between pH 5 and 12. Addition of various concentrations of $\mathrm{FeCl}_{2}$ and 2-mercaptoethanol did not increase the band intensities. The untreated control sample revealed few intense bands even on an overexposed autoradiogram.

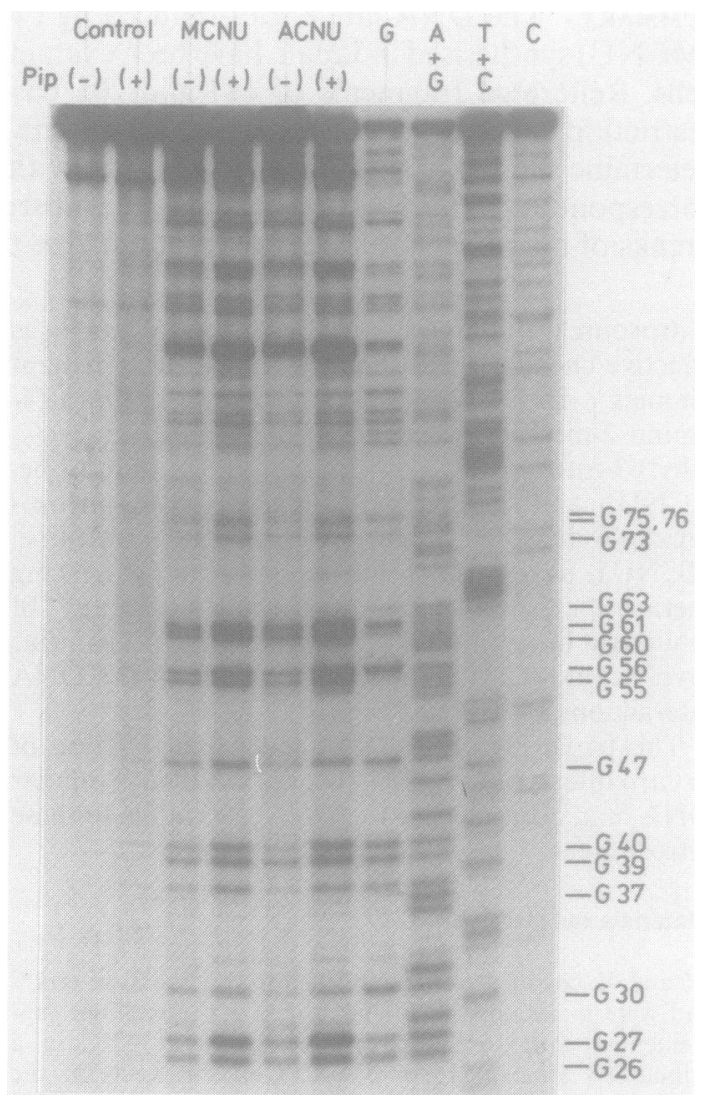

Fig 2 Autoradiogram of DNA sequence of the $167 \mathrm{bp}$ fragment from rat glioma $9 L$ cells. The 3 '-end labelling $167 \mathrm{bp}$ fragment was cleaved at guanine $(G)$, adenine and guanine $(A+G)$, thymine and cytosine $(T+C)$, and cytosine $(C)$ in the four lanes from the right. DNAs were treated in vitro for $2 \mathrm{~h}$ with $1 \mathrm{mMMCNU}$ or $1 \mathrm{mM} A C N U$ (with (+) or without (-) subsequent piperidine). Reaction of $M C N U$ or $A C N U$, with or without piperidine, formed strand scissions corresponding to guanine positions $(G)$ in the Maxam-Gilbert regular lanes. Numbers at the right hand side indicate the distance of guanine moieties in the nucleotide from the $3^{\prime}$ terminus of the 167 bp fragment. 
<smiles>Cc1ncc(CNC(=O)[N+](=O)[O-])c(N)n1</smiles><smiles>O=[N+]([O-])CC1OC2(O)COC1C(O)C(O)C2O</smiles>

Fig 3 Chemical structures of nimustine (molecular weight $309 \cdot 2)$ and ramustine (327.7).

\section{Discussion}

ACNU and MCNU (fig 3) are antitumour nitrosoureas which have been synthesised in Japan..$^{90}$ Because of their blood-brain barrier permeability, these compounds have been clinically applied in the treatment of malignant brain tumours. As with their antitumour mechanisms, DNA strand damage and inhibition of DNA synthesis have been suggested to be mediated via alkylation. ${ }^{11} 12$ Further details of drugDNA interactions have yet to be established.

The experiments shown here demonstrate that $H$ ind III-Hae III DNA fragments from rat glioma cells are suitable probes for the detection of DNA sites damaged by water soluble nitrosoureas. The DNA damage or DNA binding site of other antitumour drugs and some carcinogens have been determined using defined and known repetitive sequences. ${ }^{13-15}$ Bleomycin (BLM) showed strand scissions, potentiated by 2-mercaptoethanol, in guanine-cytosine and guanine-thymine sequences. Furthermore, neocarzinostatin (NCS) with added 2-mercaptoethanol causes DNA breaks at thymine and, to a lesser extent, adenine positions.

The synthesised nitrosoureas ACNU or MCNU caused damage or modification at positions corresponding to guanine moieties, resulting in the formation of alkali-labile sites. The site specificity of strand breaks suggests that the susceptibility of different genes may vary with their sensitivity to the effects of ACNU or MCNU. The vulnerability of guanine moieties to ACNU or MCNU is likely to be similar to that generated by other alkylating agents. ${ }^{13}$

Several functions of highly reiterated sequences have been proposed, including involvement in chromosome pairing, control of gene expression, and processing of messenger RNA precursors. ${ }^{16}$ The abundance of DNA breaks and modification induced by ACNU or MCNU in repeated sequences, especially in the guanine-rich region, can be expected to influence one or more of the above putative functions. The ultimate biological effect of the initial and unrepaired lesions in DNA, induced by the nitrosoureas, can result in tumour cell death or an alteration in biological behaviour.

ACNU was supplied by Sankyo Co, Tokyo; MCNU by Tokyo Tanabe Co, Tokyo. We thank Dr A Wakisaka for his help. This work was supported in part by a Grant-in-Aid for Scientific Research from the Ministry of Education, Science and Culture, Japan.

\section{References}

1 Walker MD, Green SB, Bvar DP, et al. Randomized comparisons of radiotherapy and nitrosoureas for the treatment of malignant gliomas after surgery. $N$ Engl J Med 1980;303:1323-9.

2 Takakura K, Abe H, Tanaka R, et al. Effects of ACNU and radiotherapy on malignant glioma. $J$ Neurosurg 1986;64:53-7.

3 Harada K, Okamoto H, Fujioka Y, et al. Clinical trial of MCNU to malignant brain tumors. Jpn $J$ Cancer Chemother (Tokyo) 1985;12:1423-31.

4 Benda P, Lightbody J, Sato G, Levine L, Sweet W. Differentiated rat glial cell strain in tissue culture. Science 1968;161:370-1.

5 Schmidek HH, Nielsen SL, Schiller AL, Messer J. Morphological studies of rat brain tumors induced by N-nitrosomethylurea. J Neurosurg 1979;34:335-40.

6 Smith HO. Recovery of DNA from gels. Methods Enzymol 1980;65:371-80.

7 Maxam AM, Gilbert W. Sequencing end-labeled DNA with base-specific chemical cleavages. Methods Enzymol 1980;65:499-560.

8 Pech M, Igo-Kemenes T, Zachau HG. Nucleotide sequence of a highly repetitive component of DNA. Nucl Acids Res 1979;7:417-32.

9 Shimizu F, Arakawa M. Effect of 3-[(4-amino-2-methyl5-pyrimidinyl)methyl]-1-(2-chloroethyl)-1-nitrosourea hydrochloride on lymphoid leukemia L-1210. Jpn J Cancer Res 1975;66:149-54.

10 Sekido S, Ninomiya K, Iwasaki M. Biologic activity of MCNU: a new antitumor agent. Cancer Treat Rev 1979;63:961-70.

11 Nakamura T, Sasada M, Tashima M, et al. Mechanism of action of 1-(4-amino-2-methyl-pyrimidin-5-yl)methyl3-(2-chloroethyl)-3-nitrosourea (ACNU) in leukemia cells. Jpn J Cancer Chemother (Tokyo) 1978; 5:991-1000.

12 Nakamura T, Hashimoto E, Sasada M, et al. Action mechanism of methyl-6-[3-(2-chloroethyl)-3-nitrosoureido]-6-deoxy- $\alpha$-D-glucopyranoside (MCNU) in 
leukemic cells. Acta Haematol Jap (Tokyo) 1985; 48:734-41.

13 Grunberg SM, Haseltine WA. Use of an indicator sequence of human DNA to study DNA damage by methylbis(2-chloroethyl)amine. Proc Natl Acad Sci USA 1980;77:6546-50.

14 Haseltine WA, Lindan CP, D'Andrea AD, Johnsrud L. The use of DNA fragments of defined sequence for the study of DNA damage and repair. Methods Enzymol 1980;65:235-48.

15 Muench KF, Misra RP, Humayun MZ. Sequence specificity in aflatoxin $\mathrm{B}_{1}$-DNA interactions. Proc Natl Acad Sci USA 1983;80:6-10.

16 Jelinek WR, Schmid CW. Repetitive sequences in eukaryotic DNA and their expression. Ann Rev Biochem 1982;51:813-44. 